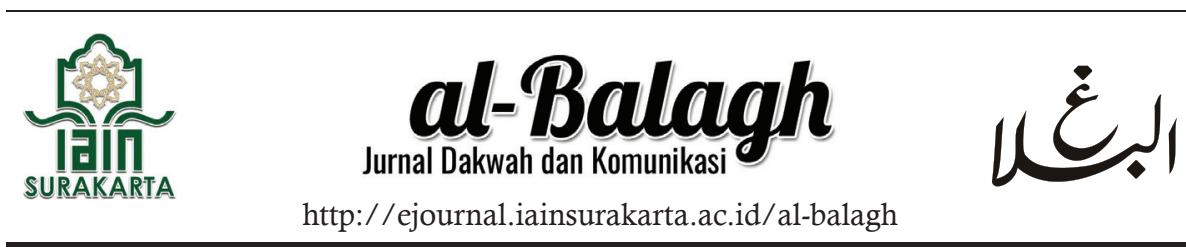

\title{
ISLAMIC HYPNOTHERAPY TO REDUCE PARENT'S ANXIETY TOWARDS THE FUTURE OF CHILDREN WITH AUTISTIC SPECTRUM DISORDERS
}

\section{Tri Winarsih}

\section{Zahro Varisna Rohmadani}

Universitas 'Aisyiyah Yogyakarta

\begin{tabular}{l}
\hline \\
\hline Keywords: \\
anxiety about \\
the child's \\
future; Islamic \\
hypnotherapy; \\
parents with autistic \\
children
\end{tabular}

\begin{abstract}
Parents of children with autism spectrum disorder (ASD) have anxiety about their children's future. This anxiety affects the psychological well-being of parents. Therefore, parents need advice to reduce their stress level. Hypnotherapy methods have been proven that those are able to reduce anxiety in various cases. For this reason, this study aims to determine the effectiveness of Islamic hypnotherapy in overcoming the fear of parents with ASD children. This study employs a pre-experimental method consisting of one group which takes treatment with the Islamic hypnotherapy method. The measurement of anxiety about the child's future was conducted by giving a scale of stress to child's future, before and after providing an intervention. The results were tested by using SPSS with Wilcoxon Signed Rank Test $Z$ $=-2.251$ and Asymp. Sig. (2-tailed $)=0.024(p<0.05)$, which mean that Islamic hypnotherapy can reduce the anxiety faced by parents who have autism children. Islamic hypnotherapy is capable of reducing stress because it teaches positive suggestions and and releases samples' emotions.
\end{abstract}

Correspondence:

e-mail: triwinarsih@unisayogya.ac.id 


\begin{tabular}{l}
\hline Kata kunci: \\
hipnoterapi \\
islami; kecemasan \\
terhadap masa \\
depan anak; \\
orang tua dengan \\
anak gangguan \\
spektrum autis \\
\hline
\end{tabular}

\section{Abstrak}

Orangtua anak dengan gangguan spektrum autis atau autism spectrum disorder (ASD) memiliki kecemasan terhadap masa depan anaknya. Kecemasan ini berpengaruh pada kesejahteraan psikologis orangtua. Oleh karena itu, orangtua sangat membutuhkan intervensi yang dapat mengurangi kecemasannya. Metode hipnoterapi telah terbukti dapat menurunkan kecemasan pada berbagai macam kasus. Untuk itu, penelitian ini ingin mengetahui efektivitas hipnoterapi islami dalam mengurangi kecemasan orangtua dengan anak ASD. Penelitian ini menggunakan metode praeksperimen, yang terdiri dari satu kelompok, yaitu kelompok yang diberikan perlakuan hipnoterapi islami. Perlakuan yang diberikan adalah metode hipnoterapi islami. Pengukuran kecemasan terhadap masa depan anak dilakukan dengan memberikan skala kecemasan terhadap masa depan anak, sebelum dan sesudah pemberian intervensi. Hasil pengisian skala diuji menggunakan SPSS dengan Wilcoxon Signed Rank Test Z=-2,25 I dan Asymp. Sig. $(2$-tailed $)=0.024(p<0,05)$, yang berarti bahwa hipnoterapi islami dapat menurunkan kecemasan yang dihadapi oleh orangtua yang memiliki anak autis. Hipnoterapi islami dapat menurunkan kecemasan karena mengajarkan sugesti positif dan pelepasan emosi pada sampel penelitian.

\section{How to cite (APA 7th Edition):}

Winarsih, T. \& Rohmadani, Z. V. (2020). Islamic Hypnotherapy to Reduce Parent's Anxiety Towards the Future of Children with Autistic Spectrum Disorders. Al-Balagh: Jurnal Dakwah Dan Komunikasi, 5(1), 1-26. https:// doi.org/10.22515/al-balagh.v5i1.1953

\section{INTRODUCTION}

All parents would serve best for their children (Syamsuddin \& Jafar, 2015). However, some parents have children with special needs, such as attention-deficit/hyperactivity disorder (Leitch et al., 2019; Subandi \& 
Rusana, 2014), mental disorder (Khamis, 2007), and deaf (Feher-Prout, 1996; Quittner et al., 2010). One of them is a child with an autistic spectrum disorder called autism spectrum disorder (ASD) (Gobrial, 2018). Diagnostic and Statistical Manual of Mental Disorder Fifth Edition (DSM V) states that children with autistic spectrum disorders have characteristics, namely difficulties in communication and social interaction, and have rigid and repetitive interests and behaviors (Durrand, Barlow, \& Hofmann, 2017, 2018; Nevid, Rathus, \& Greene, 2017). Difficulty interacting with children who have autistic disorders is distress in childcare (PastorCerezuela, Fernández-Andrés, Tárraga-Mínguez, \& Navarro-Peña, 2015; Stanojević, Nenadović, Fatić, \& Stokić, 2017). This difficulty is due to the communication skills of children with low autism disorders, which cause them to be unable to understand parental speech. Moreover, they are incapable of expressing desires, being less independent, or showing hyperactivity.

Autism spectrum disorder is one of the complex developmental disorders in children. Diagnostic and Statistical Manual of Mental Disorder Fifth Edition (DSM V) mentions the symptoms of children with autistic spectrum disorders, namely the difficulty in communicating and establishing social interactions, as well as the presence of limited and repetitive behaviors and interests. Characteristics of children with autistic spectrum disorders are in more details; first, children have communication and social interaction barriers. These barriers indicate :1) the presence of two-way (reciprocal) social and emotional interactions. For example, it is challenging to initiate interactions with others; it is difficult to respond to the communications that other people do to him; 2) There is a difficulty in showing appropriate nonverbal behavior when communicating. For instance, those children do not want do not want to look into the eyes of the speaker, ang they do not show the proper facial expressions (flat facial 
expressions); 3) There are difficulties in conducting and maintaining social relations. Particularly, these include playing alone, looking indifferent to the surrounding environment, and staying away when their friends invite them to play.

The second characteristic is that children have stereotypical and repetitive behaviors, requests, and activities. These characteristics include spinning the body under a fan that rotates on the roof, banging the neck in all conditions, and repeating the word; repeated verbal and nonverbal behaviors, such as rigid routines for example, panic and cry if the route to school changes; 4) there is a rigorous interest in the intensity and focusnot least very attached to particular objects (newspapers, bottle labels). The third characteristic is a sensory disturbance, ranging from unable to feel pain when the foot exposed to the hot exhaust; closing the ears with a strong when hearing the sound of the fan.

When children who have autistic disorders get older, another pressure arises, especially the anxiety of parents towards their children's future (Girli, 2018; Phetrasuwan \& Miles, 2009). Parents' anxiety about the future of children with autism is found in various regions. It is based on preliminary interviews conducted by researchers of five parents who have children with autism. The interview results revealed that when children with autism spectrum disorders have grown up and followed various kinds of routine therapy, the possibility of behavioral problems began to decrease. Moreover, the ability of children started to develop better. However, there are concerns about the future of children. Two parents of children worry about their children's future career. One parent with an autistic spectrum disorder child worries about the child's home, marriage, and matchmaking. Meanwhile, the five parents are worried about their child's independence, especially when the parents have have passed away.

These kinds of worries refer to parents' anxiety about child's future. In general, anxiety is defined as an unpleasant, emotional-strong feeling, 
usually followed by physical sensations that warn someone of imminent danger. This condition of discomfort is often vague and challenging to emphasize, but anxiety itself can always be felt (Feist, Feist, \& Roberts, 2017). Besides, anxiety is a state or mood which is characterized by physical symptoms, such as physical tension and worries about the future (Durrand et al., 2017, 2018). One form of anxiety is worry about future life, both one's future and others' future who are very close to him/her, for example, his/her children's future. Particularly, this condition is experienced by parents with autism spectrum disorders kids.

Espite of worriying about later life, individuals who experience anxiety will show symptoms to their limbs / physically, such as quick heartbeat, trembling, increased stomach acid, increased sweat production, and other symptoms (Adwas, Jbireal, \& Azab, 2019; Maina, Mauri, \& Rossi, 2016). Furthermore, anxiety can affect the parenting style which will harm children's psychological well-being (Wang \& Jiang, 2016; Radó, 2019) and the mental health of children (Khodabakhsh, Kiani, \& Ahmedbookani, 2014). On the other hand, anxiety that occurs in parents with autistic spectrum disorder children is also a bad indicator for the mental health of the parents themselves (Guneya, Kalafatb, \& Boysan, 2010). Based on these dynamics, it can be understood that anxiety will harm various things, not only parenting but also the psychological well-being of children. Therefore,anxiety should be overcome immediately.

There are four aspects of anxiety stated by Semiun (2006). The first characteristic is aspects of mood- not least tension, worry, panic, and irritability. People with anxiety are anxious about upcoming punishment or disaster caused by unknown sources. The second aspect relates to cognitive showing a concern for being failed and trying to avoid the failure. Third, the physical element consists of two characters, namely, direct and indirect aspects. For the direct aspect, these range from sweating, dry mouth, shortness of breath, faster pulse, increased blood pressure, throbbing Islamic Hypnotherapy to Reduce Parent's Anxiety Towards the Future of Children with Autistic Spectrum Disorders 
head, and muscle tension. In constrast, the indirect effects emerge when people persists in anxiety, and then result in elevated and chronic blood pressure, headaches, digestive processes become difficult, and pain in the stomach. Fourth, this condition also affects motoric aspects, for instance, tapping toes, plucking eyebrows, or nail-biting. These motoric activities show one's high cognitive and somatic aspects and efforts to protect oneself from something threteaning.

There are several techniques to reduce anxiety, for example, treatment with drug techniques that lower hormone levels that contribute to anxiety (Adwas et al., 2019); relaxation (Ali \& Hasan, 2010; Javanmarda \& Garegozlo, 2013); cognitive-behavioral therapy (Borkovec \& Ruscio, 2001; Huppert \& Sanderson, 2009); mindfulness therapy (Panahi \& Faramarzi, 2016); and hypnotherapy (Mubarokah, Prasetya, \& Respati, 2020; Valentine, Milling, Clark, \& Moriarty, 2019; Cowen, 2016; Setyadi, Murti, \& Demartoto, 2016). The anxiety of parents who have children with autistic disorders related to the child's future is one of the unique forms of anxiety. Thus, parents' anxiety is assumed to be treated with the various techniques mentioned.

Among those treatments for anxiety about the future of children with autism spectrum disorders, hypnotherapy is considered as a treatment with the most complete therapeutic element. For example, in hypnotherapy, there is the principle of increasing awareness or mindfulness so that both of them are realated (Grover, Jensen, Patterson, Gertz, \& Day, 2018; Simpkins \& Simpkins, 2012), even integrated into psychotherapy (Amundson, 2018). Hypnotherapy also consists of the elements of cognitive restructuring suggestions. Hence/ therefore/thus, hypnotherapy and cognitive behavioral therapy are related (Abbarin, Zemestani, Rabiei, \& Bagheri, 2018; Alladin, 2012, 2018; Fuhr, Schweizer, Meisner, \& Batra, 2017). There is an element of relaxation in hypnotherapy, therefore the two aspects relate each other (Shenefelt, 2003; Vickers \& Zollman, 1999).

Islamic Hypnotherapy to Reduce Parent's Anxiety Towards the Future of Children with Autistic Spectrum Disorders

Tri Winarsih, Zahro Varisna Rohmadani 
If there is a relaxing element in hypnotherapy, it also enables to stretch muscles and decrease the production of hormones leading to anxiety.

When examining the factors of parents' anxiety about the future of their children with autism, it is found that the cause of anxiety is related to the spirituality condition of parents with children who have autism spectrum disorders and parental understanding of God's provisions and human future. Thus, these problems can be handled through hypnotherapy by incorporating elements of spirituality and religious values. Since the respondents are Muslim, the spiritual values used in hypnotherapy are based on Islamic principles. Furthermore, there is an elaboration between hypnotherapy and Islamic values, which results in an Islamic hypnotherapy form.

Islamic hypnotherapy is one of hypnotherapy forms (Ibrahim, 2018; Ping, Hassan, Noah, Krauss, \& Zainudin, 2018). Islamic hypnotherapy has a distinctive definition from general hypnotherapy. It involves the process of putting individuals into the subconscious and providing positive suggestions. Therefore, changes in cognitive patterns occur. Also, the process of putting individuals into subconscious enables individuals to fix their affective conditions. However, Islamic approaches and internalization are used in the Islamic hypnotherapy. Islamic values in hypnotherapy help individuals to release their fears and anxieties. This hypnotherapy can be a medium for an individual to achieve trans, go beyond rational and enter into mystical and spiritual experiences, which utilize the spiritual and unconscious resources of the individual and to reach the parts of the soul that are influenced by God and the cosmos (Ping et al., 2018). Besides, Islamic hypnotherapy is a method which restores human nature as a servant and God Almighty, as a creator and tame negative egos. In accordance with Frager (1999), an individual can transform his naps or himself into more positive ones.

There have been various previous studies examining the effects Islamic Hypnotherapy to Reduce Parent's Anxiety Towards the Future of Children with Autistic 
of hypnotherapy on anxiety. For example, the research conducted by Mubarokah, Prasetya, \& Respati (2020); Valentine, Milling, Clark, \& Moriarty (2019); Cowen (2016); Setyadi, Murti, \& Demartoto (2016); Kumar \& Jena (2013); Shestopal (2014); Annisa, Afdal, Daharnis, \& Adlya (2019); Santoso \& Dewi (2014); Rohmadani (2017); Valentine et al. (2019); Alladin (2016). On the other hand, there are previous studies that examine hypnotherapy to deal with other problems, such as depression (Alladin, 2018); body dysmorphic disorder (Abbarin et al., 2018); and perception of injury (Schulz-Stübner et al., 2004). Besides, research on Islamic hypnotherapy has also been carried out by Trimulyaningsih, Wulandari, \& Sofia (2017); Ibrahim (2018); and Ping, Hassan, Noah, Krauss, \& Zainudin (2018). The difference between this research and previous research is on several aspects-first, the theme aspect. The theme in this study is specifically related to Islamic hypnotherapy to reduce levels of anxiety.

In contrast, prior studies focus on general hypnotherapy themes to reduce levels of anxiety. Also, other problems have been handled in those studies, for example, the variables of depression, perception of wounds, and body dysmorphic disorders. The second aspect is the research sample. The research sample used in this study is parents who have children with autism spectrum disorders, therefore it differs from previous research samples. The third distinct aspect is the research method. This research employs the experimental process, while there are previous studies that use the experimental method, the case study, and the literature review. Lastly, the difference is in the instruments for measurement. Anxiety measurement tool in this research adopts Semiun's theory (2006) which differs it from other literature.

The research objective is to determine the effect of the Islamic hypnotherapy method to reduce parental anxiety towards children's future with autism spectrum disorders. This study hypothesizes that Islamic hypnotherapy can reduce parents' anxiety about children's future life with autism spectrum disorders with autism spectrum disorders. 


\section{METHODS}

The subjects in this study were parents of children with autism spectrum disorders who participated in the therapy program at the Yogyakarta Autism Service Center. Those parents had high anxiety based on the pretest research, and expressed willingness to take part in the study. Subjects consisted of ten mothers who had children with autism spectrum disorders with an age range of 9-12 years. The sampling technique used was non-random sampling.

The dependent variable was the research problem, namely parents' anxiety about the future of their children who have autism spectrum disorders. Meanwhile, the independent variable was Islamic hypnotherapy as the treatment in this study.

The operational definition of Islamic hypnotherapy is one of the interfering method or treatment which empowers the subconscious of the subject group by using the Islamic concept, and this concept is given to the subject group during the process/in the deepening part when giving suggestions to this group. Islamic hypnotherapy was given to the group of subjects three times started by exploring the subject matter and also relaxation.

The operational definition of parental anxiety of the future of children who have autism spectrum disorders is a condition of worry, irritability, and feeling the existence of a threatening punishment or disaster. If the individual thinks about the future of his child who has autism spectrum disorders, it will change on cognitive aspects, somatic aspects, and motor aspects. First, the cognitive element, a person who feels anxious about the future, tends to have bad thoughts about the future of his child who has autism spectrum disorders. Second, the physical aspect relates to the emergence of physiological reactions (heart beat faster, sweating hands, indigestion, etc.) when thinking and feeling 
anxious if something worse will happen in the future of children who have autistic spectrum disorders. Third, the motor aspect which appears when someone concerned about the future of his child who has autism spectrum disorders, can be seen inmotor movements such as trembling hands, fingers tapping, feet rocking repeatedly, and others. Parents' anxiety about the future of children with autistic spectrum disorders was measuredby a measurement tool or scaleof parental anxiety about the future of children with autistic spectrum disorders. If the measurement results show a high score, it indicates a high level of anxiety. However, if the measurement results show a low grade, then it means a low level of anxiety.

The treatments used in this study were the Islamic hypnotherapy module and parental anxiety measurement tools for the future of children with autistic spectrum disorders. The Islamic hypnotherapy module was a tool to provide intervention which contains guidance for therapists or researcher. It was used to provide Islamic hypnotherapy to the subject. Anxiety measurement tool used a parent's anxiety scale for the future of children with autistic spectrum disorders compiled by researchers referring to three aspects of anxiety raised by Semiun (2006). Besides, to enrich research data, researchers conducted interviews with subjects and analyzed the subject's notes in a diary during Islamic hypnotherapy interventions.

The research design used in this study iswas the design of the experiment with one group pretest-posttest design. The model consistedof one group of subjects given measurements before and after treatment; then, the two measurements will be compared to determine the effect of treatment (Latipun, 2015; Saifuddin, 2019; Seniati, Yulianto, \& Setiadi, 2005). 


\begin{tabular}{|llll|}
\hline NR & O1 & $X$ & O2 \\
\hline
\end{tabular}

Figure 1. Pra-experiment Design

Which is :

NR : Non-Random

O1 : Pre-treatment measurements / before treatment (pretest)

O2 : Post-treatment measurements / after treatment (posttest)

$\mathrm{X} \quad$ : Treatment by using Islamic hypnotherapy

The validity of the measuring instrument used in this study was the content validity. The content validity is considered considered to be on target if the items on it are in accordance with are in harmony with behavioral aspects and indicators, as well as in line with the measurement objectives so that they can reveal the construct to be measured. Content validity consists of two, namely the face validity and content validity. The face validity is applied by making the measuring instrument exciting and easy to read so that the research subjects do not lose the urge to fill the measuring instrument. Meanwhile, content validity was performed by asking experts in preparation for measuring instruments and constructors of anxiety. It was used to assess the suitability and accuracy of the target of each item in the measuring instrument compiled. The assessment results were then calculated using the Aiken's V formula (Aiken, 1985; Azwar, 2016; Saifuddin, 2020).

This study involved five experts in the field of psychological measurement and psychological constructs of anxiety. The results of calculations using the Aiken's $\mathrm{V}$ formula produced an item validity index ranging from 0.800 to 0.933 . Therefore, the items in the measuring instrument were considered valid. The item difference power wascalculated using the corrected item-total correlation, resulting in an item difference coefficient between 0.285 to 0.743 . 
Then, reliability is defined as the consistency of the measurement results from time to time. The reliability method used in this study wasthe method of internal consistency or single-trial administration, where the researcher made a measuring instrument and then was tested on a group of people who have characteristics that were equivalent to the group of research subjects. The trial results were then calculated using the Alpha formula. The reliability of the measuring instrument wasconsidered good if the estimated score of the reliability coefficient was more than 0.700 (Azwar, 2016; Saifuddin, 2020; DeVellis, 2016). Meanwhile, the Alpha reliability coefficient measuring the instrument anxiety of parents towards the future of children with autistic spectrum disorders was 0.903. It means that the measuring instrument was considered to have high reliability/ consistency because it exceeded the minimum reliability coefficient.

\section{RESULTS AND DISCUSSION}

\section{Research Results}

Hypothesis testing in this study used the Wilcoxon Signed Rank Test technique, which is a nonparametric analysis technique to test the differences in the two measurements applied to one group (Saifuddin, 2019). The nature of the data in this study was nonparametric because it did not meet three criteria as parametric data. Those criteria included are a large number of research subjects, the type of score calculated is the interval or ratio, and passing the assumption test. Although the score in this study was an interval score, the number of research subjects was only ten people, hence the first requirement to be parametric was not met. Therefore, the nature of the data in this study was nonparametric. The results of hypothesis testing using the Wilcoxon Signed Rank Test technique were as follows: 
Table 1.

Results of different anxiety levels using the Wilcoxon Signed Rank Test

\begin{tabular}{ll}
\hline & Posttest - Pretest \\
\hline$Z$ & -2.251 \\
\hline Asymp. Sig. (2-tailed) & .024 \\
\hline
\end{tabular}

Based on the results of these calculations, it was foundthat the level of anxiety of people towards the future of children with autism spectrum disorders has decreased shown by the magnitude of the $\mathrm{Z}$ score of -2.251 and the significance level of $0.024(\mathrm{p}<0.050)$. Results of data analysis show that there were differences in the level of anxiety of parents towards the future of their children with significant autism spectrum disorders between before and after being treated by using Islamic hypnotherapy.

Table 2.

Comparison of Parents' Anxiety Scores for the Future of Children With Autistic Spectrum Disorders Between Pretest And Posttest

\begin{tabular}{ccccc}
\hline No & Research Subject & $\begin{array}{c}\text { Pretest Anxiety } \\
\text { Score }\end{array}$ & $\begin{array}{c}\text { Posttest Anxiety } \\
\text { Score }\end{array}$ & $\begin{array}{c}\text { Score } \\
\text { Difference }\end{array}$ \\
\hline 1 & Subject 1 & 82 & 71 & 11 \\
\hline 2 & Subject 2 & 71 & 67 & 4 \\
\hline 3 & Subject 3 & 71 & 64 & 7 \\
\hline 4 & Subject 4 & 51 & 52 & -1 \\
\hline 5 & Subject 5 & 78 & 70 & 8 \\
\hline 6 & Subject 6 & 69 & 66 & 3 \\
\hline 7 & Subject 7 & 69 & 68 & 1 \\
\hline 8 & Subject 8 & 74 & 77 & -3 \\
\hline 9 & Subject 9 & 79 & 76 & 3 \\
\hline 10 & Subject 10 & 73 & 69 & 4 \\
\hline & Total & 717 & 680 & 37 \\
\hline
\end{tabular}

This following graph compares the results of subjects' anxiety score towards the future of their child with autism spectrum disorders before (pretest) and after (posttest) being treated through Islamic hypnotherapy: 
Al-Balagh: Jurnal Dakwah dan Komunikasi,

Vol. 5, No. 1, January - June 2020, pp. 1 - 26, DOI: https://doi.org/10.22515/al-balagh.v5i1.1953

ISSN: 2527-5704 (P) ISSN: 2527-5682 (E

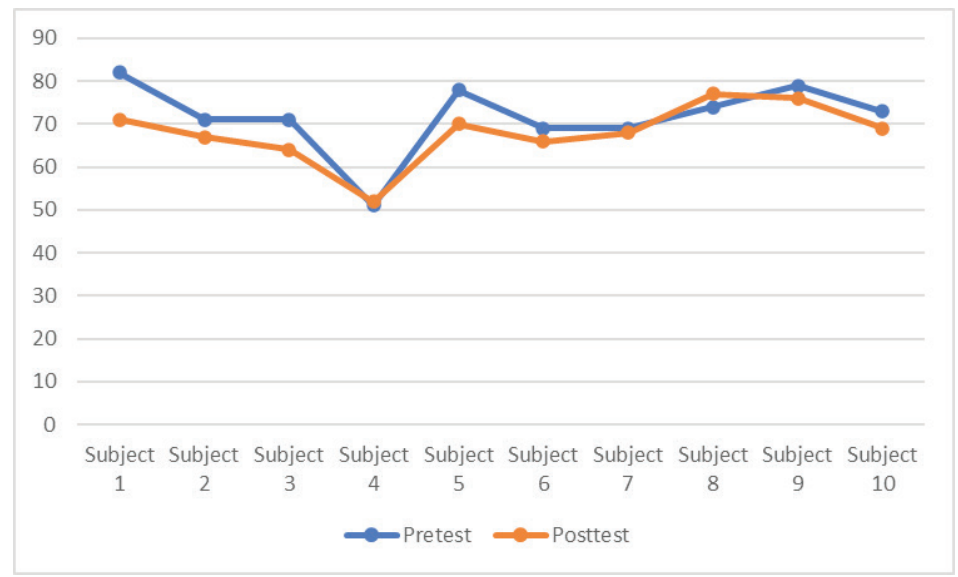

Figure 2. Graphic Comparison of Parents' Anxiety Scores Against Their Child's Future With Autism Spectrum Disorders Between Pre-test and Post-test

Based on these graphs, it can be seen that the anxiety level of eight subjects towards the future of their children with autism spectrum disorders decreased after getting treated in the form of Islamic hypnotherapy. Based on interviews and diaries, the study subjects reported that after getting Islamic hypnotherapy, they felt calmer, more relieved, and sincere. They also can reduce their negative thoughts and less concerned about the future of children. They were also being more optimistic about the future of children and families, more trust self-caring for children, and able to hold their anger.

Table 3.

Summary of Research Subject Interview Results

\begin{tabular}{lll}
\hline No & Subject & The Interview Results After Treatment \\
\hline 1 & Subject 1 & Previously felt angry, tense. After the session: felt calm; less anger. \\
\hline 2 & Subject 2 & $\begin{array}{l}\text { After attending hypnotherapy, she felt calmer, more optimistic } \\
\text { about her child's abilities. }\end{array}$ \\
\hline 3 & Subject 3 & $\begin{array}{l}\text { After participating in hypnotherapy: feel calmer and can return } \\
\text { all worries to God. }\end{array}$ \\
\hline 4 & Subject 4 & $\begin{array}{l}\text { Subject 4, before hypnotherapy: feltmediocre, stayedoptimistic. } \\
\text { After hypnotherapy: kept feeling calm and optimistic }\end{array}$ \\
\hline
\end{tabular}




\begin{tabular}{|c|c|c|}
\hline No & Subject & The Interview Results After Treatment \\
\hline 5 & Subject 5 & $\begin{array}{l}\text { Before hypnotherapy: worried, concerned about the child's } \\
\text { current condition and future. After attending hypnotherapy: } \\
\text { feeling calmer, not suffering anymore, believing that her child will } \\
\text { be able to be independent. }\end{array}$ \\
\hline 6 & Subject 6 & $\begin{array}{l}\text { Before attending hypnotherapy: feeling anxious about the child's } \\
\text { condition. After attending hypnotherapy: feeling more optimistic } \\
\text { and more confident and being able to accompany the child so } \\
\text { that the child can improve his abilities. }\end{array}$ \\
\hline 7 & Subject 7 & $\begin{array}{l}\text { Before joining hypnotherapy, he felt uneasy with the child's } \\
\text { condition at this time (there was no significant improvement } \\
\text { on the abilityon the ability to develop themselves and their } \\
\text { communication, moreover, frequent convulsions lead to a } \\
\text { decrease of their ability, therefore the ability decreased, etc.). } \\
\text { Besides, he easily got temper with his child behavior. After } \\
\text { participating in hypnotherapy: being able to accept the child's } \\
\text { condition (it's not easy to improve children's abilities, I have to } \\
\text { be patient and keep trying), besides negative thoughts (whether } \\
\text { his child can be like ordinary children and be healthy) about the } \\
\text { child was getting deminished. In addition, it can reduce anger at } \\
\text { children when children make them angry (for example, hard to } \\
\text { teach, or damaging the goods). }\end{array}$ \\
\hline 8 & Subject 8 & $\begin{array}{l}\text { Before hypnotherapy: easily angry and sad when the child was } \\
\text { difficult to control, besides feeling worried about the child's } \\
\text { current condition and in the future. Despite of autism, the child } \\
\text { also experiences hearing and visual impairments so that the } \\
\text { mother worried whether someday she can be independent to do } \\
\text { all the activities, and fulfill their needs without relying on others? } \\
\text { After attending hypnotherapy: they feel calmer, less worrying, } \\
\text { and the important thing is still trying to educate and care for the } \\
\text { child properly. }\end{array}$ \\
\hline 9 & Subject 9 & $\begin{array}{l}\text { Before hypnotherapy felt dizzy when thinking about the future } \\
\text { of their children (why children can neither be independent } \\
\text { nor communicate properly with others, etc, etc.). Also, he/she } \\
\text { was easily angry with his child behavior.. After participating in } \\
\text { hypnotherapy: feeling calmer when thinking about the child's } \\
\text { future, and more sincere, and tryingharder to pray. It also becomes } \\
\text { easier to control anger when children do not want to sit quietly } \\
\text { or when children are difficult to be taught to do something (daily } \\
\text { independence activities such as wearing clothes, eating, etc.). }\end{array}$ \\
\hline
\end{tabular}




\begin{tabular}{lll}
\hline No & Subject & The Interview Results After Treatment \\
\hline 10 & Subject & $\begin{array}{l}\text { Before hypnotherapy: easily getting emotional and angry when } \\
\text { children run, pinch people, and are dependent, etc. After } \\
\end{array}$ \\
& $\begin{array}{l}\text { hypnotherapy: feeling calmer, not easily upset when the child is } \\
\text { making noise or unable to be independent. }\end{array}$ \\
\hline
\end{tabular}

Based on the interview data after the treatment of Islamic hypnotherapy was given, nine research subjects stated calmer and had less anxiety.

\section{Discussion}

The treatment of Islamic hypnotherapy has several therapeutic elements so that it can reduce the level of anxiety of parents towards the future of their children who experience autism spectrum disorders. The element of relaxation in hypnotherapy (Khan et al., 2010; Shenefelt, 2003; Vickers \& Zollman, 1999; Facco, 2017), which is included in Islamic hypnotherapy (Ping et al., 2018) allowed subjects to have a convenient situation during the treatment. Furthermore, this also required research subjects to manage their breathing. Due to the comfort and regulation of the breath, the body's condition relaxes. In detail, the heart rate decreases, blood flow becomes smooth but not tight, muscle tension decreases, which results in a drop of sympathetic nerve activity (Benson, Arns, \& Hoffman, 1981).

During the Islamic hypnotherapy session, the research subjects were also given positive suggestions. This positive suggestion provides some psychological dynamics in the matter of research-for example, the occurrence of cognitive restructuring, namely the replacement of irrational thoughts into rational. In the cognitive-behavioral paradigm, anxiety arises due to irrational thoughts and beliefs (Alford \& Beck, 1997; Beck \& Weishaar, 2005; Nelson-Jones, 2014). One form of ridiculous thinking and feeling is to believe something or events that have not yet 
happened, including future developments, as something certain to occur. When a belief in something or a next event is a negative belief, it will raise anxiety. This condition is experienced by the research subjects. Therefore, during the Islamic hypnotherapy session, the research subjects were given positive suggestions to replace the irrational mind with a more rational soul, that everything that has not yet happened has many possibilities. These possibilities can be managed. In other words, a good future can be pursued with various efforts. In the end, parents' anxiety about the future of children who have autism spectrum disorders decreases.

Positive suggestions were also intended to handle gremlin or negative ego. During the Islamic hypnotherapy session, the research subjects were suggested to visualize the negative thought. Research subjects were told that the source of anxiety was the negative ego, hence it needed to be controlled. After this, the research subjects were suggested to control or tame it. Thus, the anxiety decreased (Carson, 1983; Collins-Donnelly, 2013). On the other hand, Vasel, Farhadi, Paidar, \& Chegini (2016), hypnotherapy can overcome the existence of negative self-talk that comes from negative egos as a cause of anxiety, so that stress can be reduced.

Islamic hypnotherapy also contains encouragement for research subjects to be trusting/surrender to God or tawakal. As spiritual beings, submission to God is a value that should be applied. Regarding various possibilities about the future of children with autism spectrum disorders, tawakal attitude is expected to reduce anxiety. The possible reason is because tawakal encourages individuals to reduce their negative thinking and believe in God to hold the authority . Based on Bakri \& Saifuddin (2019), tawakal attitude can reduce mental stress. Therefore, Islamic hypnotherapy which encourages the research participants to be tawakkal can overcome anxiety. Research subjects stated they felt more relieved after being treated with Islamic hypnotherapy. 
Another suggestion made during Islamic hypnotherapy is to encourage individuals to think positively about the future. Thinking positively about the future can be done by imagining good events that are expected or often termed imagery. When the research subjects believe in good things, it will develop positive emotions as well. These positive emotions then reduce anxiety so that anxiety can decrease. Furthermore, according to Blackwell \& Holmes (2017), this imagery is able to provide several benefits, for example, improving mood, raising positive expectations, and motivating positive behavior. Thus, representation can change the cognitive, emotional, and expression of individuals (Blackwell, 2019). Therefore, imagery enables a decrease in the anxiety level.

When the research subject was given some suggestion to imagine a positive event or imagery, it would encourage the person achieve it. Thus, in this case, Islamic hypnotherapy also creates motivation for research subjects to try to make a good future for themselves and their children with autism spectrum disorders. Furthermore, according to Kumar \& Singh (2015), hypnotherapy can help individuals who are diagnosed with anxiety symptoms to experience a decrease in anxiety. Hypnotherapy can touch the root of individual problems stored in the subconscious mind so that it is capable of reducing anxiety effectively.

Alladin (2016) suggests that hypnotherapy has hypnotherapy releases a relaxing effect, a mind power to control over the body, a rise of awareness, a symptom regulation, and a suggestion. Likewise, the Islamic hypnotherapy as a form of hypnotherapy, also contains such components. Relaxation causes the subject's mind and body condition to be more relaxed due to a decrease in sympathetic nerve activity. A demonstration of the mind power for a body control encourages research subjects to control their thoughts in order to avoid unexpected impacts on the body, therefore a lower level of anxiety can be achieved. An increase in awareness leads the research subject to realize that anxiety has a negative impact and 
discomfort on the mental condition, and come to realize that they have a potential ability to resolve stress by themselves. Thus, research subjects can handle the symptoms of anxiety. Suggestion influences research subjects to think positively, be surrender to God, and encourage them to achieve something that is visualized during the hypnotherapy process. Finally, the anxiety of research subjects regarding the future of their children with autism spectrum disorders decreased.

Although this research convinces that Islamic hypnotherapy can reduce parents' anxiety about the future of their children with autism spectrum disorders, there are some limitations in the study: first, the small number of research subjects. Based on the sampling used, researchers only found ten parents from an entire population of parents with autistic spectrum disorder children who had high anxiety. Second, the small number of subjects impacts on less possibility of choosing experimental designs. Therefore, the experimental design used in this study was a preexperiment with the design of a group given pretest and posttest. Hence, the comparison can only be made on the results of the pretest and posttest because this study did not use a comparative group (control group).

\section{CONCLUSION AND SUGGESTION}

\section{Conclusion}

Based on the results of the study, it can be concluded that Islamic hypnotherapy can reduce parental anxiety about the future of children who have autism spectrum disorders. The anxiety level of parents is reduced after attending Islamic hypnotherapy. The research subjects also reported the emergence of positive emotions and thoughts after attending the entire Islamic hypnotherapy session, such as feeling calmer, relieved, sincere, less negative thoughts, more optimistic, more confident, and easy to control emotions when angry. It is because, in Islamic hypnotherapy, there are mechanisms of suggestion, imagery, relaxation, cognitive restructuring, and submission to reduce the level of anxiety. 


\section{Suggestion}

The next researcher can involve more research subjects so that it is possible to divide the subject into two groups with a relatively large number of each group. Thus, the nature of research data has a possibility to be parametric. Then, researchers can then control various variables that have some possible effects to lead a bias in the research.

\section{REFERENCES}

Abbarin, M., Zemestani, M., Rabiei, M., \& Bagheri, A. H. (2018). Efficacy of Cognitive-Behavioral Hypnotherapy on Body Dysmorphic Disorder: Case Study. Iranian Journal of Psychiatry and Clinical Psychology, 23(4), 394-407. https://doi.org/10.29252/nirp. ijpcp.23.4.394

Adwas, A. A., Jbireal, J. M., \& Azab, A. E. (2019). Anxiety: Insights into Signs, Symptoms, Etiology, Pathophysiology, and Treatment. East African Scholars Journal of Medical Sciences, 2(10), 580-591.

Aiken, L. R. (1985). Three Coefficients for Analyzing Reliability and Validity of Ratings. Educational and Psychological Measurement, 45, 131-142. https://doi.org/10.1177/07399863870092005

Alford, B. A., \& Beck, A. T. (1997). The Integrative Power of Cognitive Therapy. New York, USA: Guilford Press.

Ali, U., \& Hasan, S. (2010). The Effectiveness of Relaxation Therapy in the Reduction of Anxiety Related Symptoms (A Case Study). International Journal of Psychological Studies, 2(2), 202-208. https:// doi.org/10.5539/ijps.v2n2p202

Alladin, A. (2012). Cognitive Hypnotherapy: A New Vision and Strategy for Research and Practice. American Journal of Clinical Hypnosis, 54(4), 249-262. https://doi.org/10.1080/00029157.2012.654528

Alladin, A. (2016). Cognitive Hypnotherapy for Accessing and Healing Emotional Injuries for Anxiety Disorders. American Journal of Clinical Hypnosis, 59(1), 24-46. https://doi.org/10.1080/0002915 7.2016.1163662 
Alladin, A. (2018). Cognitive Hypnotherapy for Psychological Management of Depression in Palliative Care. Annals of Palliative Medicine, 7(1), 112-124. https://doi.org/10.21037/apm.2017.08.15

Amundson, J. K. (2018). Mindfulness-Based Hypnotherapy. American Journal of Clinical Hypnosis, 61(1), 1-3. https://doi.org/10.1080/00 029157.2018.1465282

Annisa,D.F.,Afdal,A.,Daharnis,D., \&Adlya,S.I.(2019).Hypnotherapyasan Alternative Approach in Reducing Anxiety in the Elderly. Counselor, Vol. 8, pp. 32-37. https://doi.org/10.24036/0201874102696-0-00

Azwar, S. (2016). Reliabilitas dan Validitas (4 Ed). Yogyakarta: Pustaka Pelajar.

Bakri, S., \& Saifuddin, A. (2019). Sufi Healing: Integrasi Tasawnf dan Psikologi Dalam Penyembuban Psikis dan Fisik. Depok: Rajagrafindo Persada.

Beck, A. T., \& Weishaar, M. E. (2005). Cognitive Therapy. In R. J. Corsini \& D. Wedding (Eds.), Current Psychotherapies (7th Ed, pp. 238-268). Belmont: Thomson Brooks/ Cole.

Benson, H., Arns, P. A., \& Hoffman, J. W. (1981). The Relaxation Response and Hypnosis. InternationalJournalof ClinicalandExperimentalHypnosis, 29(3), 259-270. https://doi.org/10.1080/00207148108409160

Blackwell, S. E. (2019). Mental Imagery: From Basic Research to Clinical Practice. Journal of Psychotherapy Integration, 29(3), 235-247. https:// doi.org/10.1037/int0000108

Blackwell, S. E., \& Holmes, E. A. (2017). Brightening the Day With Flashes of Positive Mental Imagery: A Case Study of an Individual With Depression. Journal of Clinical Psychology, 73(5), 1-11. https://doi. org $/ 10.1002 /$ jclp. 22455

Borkovec, T. D., \& Ruscio, A. M. (2001). Psychotherapy for Generalized Anxiety Disorder. The Journal of Clinical Psychiatry, 62(11), 37-45.

Carson, R. D. (1983). Taming Your Gremlin: A Guide to Enjoying Yourself. Family Resource.

Collins-Donnelly, K. (2013). Starving the Anger Gremlin: A Cognitive Behavioural Therapy Workbook on Anger Management for Young People. London, United Kingdom: Jessica Kingsley Publishers.

Cowen, L. W. (2016). Literature Review into the Effectiveness of Hypnotherapy. Australian Counseling Research Journal, 1, 1-55. 
DeVellis, R. F. (2016). Scale Development: Theory and Applications (4th Ed). Thousand Oaks, California, United States: SAGE Publications.

Durrand, V. M., Barlow, D. H., \& Hofmann, S. G. (2017). Abnormal Psychology: An Integrated Approach (8th Ed). Boston, Massachusetts, United States: Cengage Learning.

Durrand, V. M., Barlow, D. H., \& Hofmann, S. G. (2018). Essentials of Abnormal Psychology (8th Ed). Boston, Massachusetts, United States: Cengage Learning.

Facco, E. (2017). Meditation and Hypnosis: Two Sides of the Same Coin? International Journal of Clinical and Experimental Hypnosis, 65(2), 169188. https:// doi.org/10.1080/00207144.2017.1276361

Feher-Prout, T. (1996). Stress and Coping in Families with Deaf Children. Journal of Deaf Studies and Deaf Education, 1(3), 155-166.

Feist, J., Feist, G. J., \& Roberts, T.-A. (2017). Theories Of Personality (8th Ed). New York, USA: McGraw-Hill Education (Asia).

Frager, R. (1999). Heart, Self, and Soul: The Sufi Psychology of Growth, Balance, and Harmony. Wheaton, Illinois: Quest Books.

Fuhr, K., Schweizer, C., Meisner, C., \& Batra, A. (2017). Efficacy of Hypnotherapy Compared to Cognitive-Behavioural Therapy for Mild-to-moderate Depression: Study Protocol of a Randomisedcontrolled Rater-blind Trial (WIKI-D). BMJ Open, 7, e016978. https://doi.org/10.1136/ bmjopen-2017-016978

Girli, A. (2018). Being a Parent of a Child With Autism from Diagnosis to the University Years. Journal of Education and Training Studies, 6(5), 55. https://doi.org/10.11114/jets.v6i5.3146

Gobrial, E. (2018). The Lived Experiences of Mothers of Children with the Autism Spectrum Disorders in Egypt. Social Sciences, 7(133), 1-11. https://doi.org/10.3390/socsci7080133

Grover, M. P., Jensen, M. P., Patterson, D. R., Gertz, K. J., \& Day, M. A. (2018). The Association Between Mindfulness and Hypnotizability: Clinical and Theoretical Implications. American Journal of Clinical Hypnosis, 61(1), 4-17. https://doi.org/10.1080/00029157.2017.1 419458 To

Guneya, S., Kalafatb, T., \& Boysan, M. (2010). Dimensions of Mental Health: Life Satisfaction, Anxiety, and Depression: A Preventive Mental Health Study in Ankara University Students Population. 
Procedia Social and Behavioral Sciences, 2, 1210-1213. https://doi. org/10.1016/j.sbspro.2010.03.174

Huppert, J. D., \& Sanderson, W. C. (2009). Psychotherapy for Generalized Anxiety Disorder. In D. J. Stein, E. Hollander, \& B. O. Rothbaum (Eds.), Textbook of Anxiety Disorders (pp. 253-274). Virginia, United States: American Psychiatric Association Publishing.

Ibrahim. (2018). Kesehatan Ala Hipnoterapi Islam. Jurnal Ilmiah Syi'ar, 18(2), 103-115. https://doi.org/10.29300/syr.v18i2.1684

Javanmarda, G. H., \& Garegozlo, R. M. (2013). The Effectiveness of Relaxation Training on Anxiety of Disordered Children's Mothers. Procedia - Social and Behavioral Sciences, 84, 341 - 345. https://doi. org/10.1016/j.sbspro.2013.06.563

Khamis, V. (2007). Psychological Distress Among Parents of Children with Mental Retardation in the United Arab Emirates. Social Science \& Medicine, 64(4), 850-857. https://doi.org/10.1016/j. socscimed.2006.10.022

Khan, N., Ahmad, N. bt, Beg, A. H., Fakheraldin, M. A. I., Alla, A. N. A., \& Nubli, M. (2010). Mental and Spiritual Relaxation by Recitation of the Holy Quran Nawsher. Second International Conference on Computer Research and Development Mental, 863-867. https://doi. org/10.1109/ICCRD.2010.62

Khodabakhsh, M. R., Kiani, F., \& Ahmedbookani, S. (2014). Psychological Well-being and Parenting Styles as Predictors of Mental Health among Students: Implication for Health Promotion. International Journal of Pediatrics (Supplement 5), 2(3-3), 39-46.

Kumar, A., \& Jena, S. P. K. (2013). Effect of Clinical Hypnotherapy on Anxiety Symptoms. Delhi Psychiatry Journal, 16(1), 134-139.

Kumar, U., \& Singh, A. P. (2015). Hypnotherapy and Relaxation Intervention on Anxiety and Depression Level of HIV/AIDS Patients. Indian Journal of Applied Research, 5(1), 532-533. https:/ / doi.org/10.36106/ijar

Latipun. (2015). Psikologi Eksperimen. Malang: UMM Press.

Leitch, S., Sciberras, E., Post, B., Gerner, B., Rinehart, N., Nicholson, J. M., ... To. (2019). Experience of Stress in Parents of Children with ADHD: A Qualitative Study. International Journal of Qualitative Studies on Health and Well-Being, 14(1), 1690091. https:/ / doi.org/10 
Maina, G., Mauri, M., \& Rossi, A. (2016). Anxiety and Depression. Journal of Psychopathology, 22(4), 236-250. https://doi.org/10.5005/jp/ books/18030_26

Mubarokah, R. I., Prasetya, H., \& Respati, S. H. (2020). The Effectiveness of Hypnotherapy to Reduce Anxiety in Pre-caesarean Section Women. Journal of Maternal and Child Health, 5(1), 12-18. https:// doi.org/10.26911/thejmch.2020.05.01.02

Nelson-Jones, R. (2014). Theory and Practice of Counselling and Psychotherapy (4th Ed). Thousand Oaks, California, United States: SAGE Publications Ltd.

Nevid, J. S., Rathus, S. A., \& Greene, B. (2017). Abnormal Psychology in a Changing World (10th Ed). London, UK: Pearson Education, Inc.

Panahi, F., \& Faramarzi, M. (2016). The Effects of Mindfulness-Based Cognitive Therapy on Depression and Anxiety in Women with Premenstrual Syndrome. Depression Research and Treatment, 2016, 1-8. https://doi.org/10.1155/2016/9816481

Pastor-Cerezuela, G., Fernández-Andrés, M. I., Tárraga-Mínguez, R., \& Navarro-Peña, J. M. (2015). Parental Stress and ASD: Relationship with Autism Symptom Severity, IQ, and Resilience. Focus on Autism and Other Developmental Disabilities, 31(4), 1-12. https://doi. org/10.1177/1088357615583471

Phetrasuwan, S., \& Miles, M. S. (2009). Parenting Stress in Mothers of Children with Autism Spectrum Disorders. Journal for Specialists in Pediatric Nursing, 14(3), 157-165. https://doi.org/10.1111/j.17446155.2009.00188.x

Ping, S. L. S., Hassan, S. A., Noah, S. M., Krauss, L. S., \& Zainudin, Z. N. (2018). Unveiling the Experiences through Feeling in Undergoing Spiritual Hypnotherapy with Islamic Approach (SPHIA) for Female Children Victim of Incest. International Journal of Academic Research in Business and Social Sciences, 8(6), 507-519. https://doi. org/10.6007/IJARBSS/v8-i6/4254

Quittner, A. L., Barker, D. H., Cruz, I., Snell, C., Grimley, M. E., Botteri, M., \& Team, the Cd. I. (2010). Parenting Stress among Parents of Deaf and Hearing Children: Associations with Language Delays and Behavior Problems. Parenting: Science and Practice, 10(2), 136- 
155. https:// doi.org/10.1080/15295190903212851

Radó, M. K. (2019). Tracking the Effects of Parenthood on Subjective Well-Being: Evidence from Hungary. Journal of Happiness Studies. https://doi.org/10.1007/s10902-019-00166-y

Rohmadani, Z. V. (2017). Metode Future Pacing Hypnotherapy Untuk Menurunkan Tingkat Kecemasan Pada Mahasiswa Baru. Journal of Health Studies, 1(2), 125-129. https://doi.org/10.31101/jhes.249

Saifuddin, A. (2019). Penelitian Eksperimen Dalam Psikologi. Jakarta: Kencana. Saifuddin, A. (2020). Penyusunan Skala Psikologi. Jakarta: Kencana.

Santoso, W. W., \& Dewi, D. K. (2014). Efektifitas Hypnotherapy Teknik Direct Suggestion Untuk Menurunkan Kecemasan Mahasiswa Terhadap Skripsi. Character, 3(2), 1-6. https://doi. org/10.1007/978-3-642-28753-4_200593

Schulz-Stübner, S., Krings, T., Meister, I. G., Rex, S., Thron, A., \& Rossaint, R. (2004). Clinical Hypnosis Modulates Functional Magnetic Resonance Imaging Signal Intensities and Pain Perception In A Thermal Stimulation Paradigm. Regional Anesthesia and Pain Medicine, 29(6), 549-556. https://doi.org/10.1016/j.rapm.2004.09.002

Semiun, Y. (2006). Kesehatan Mental. Yogyakarta: Kanisius.

Seniati, L., Yulianto, A., \& Setiadi, B. N. (2005). Psikologi Eksperimen. Jakarta: Penerbit Indeks.

Setyadi, A. W., Murti, B., \& Demartoto, A. (2016). The Effect of Hypnotherapy on Depression, Anxiety, and Stress, in People Living with HIV/AIDS, in "Friendship Plus" Peer Supporting Group, in Kediri, East Java. Journal of Health Promotion and Behavior, 1(2), 100-109. https:/ / doi.org/10.26911/thejhpb.2016.01.02.05

Shenefelt, P. D. (2003). Hypnosis-Facilitated Relaxation Using Self-Guided Imagery During Dermatologic Procedures. American Journal of Clinical Hypnosis, 45(3), 225-232. https://doi.org/10.1080/00029 157.2003.10403528

Shestopal, I. (2014). Hypnotherapy for Anxiety in Private Practice: SCL-90 Results and Case Description. Contemporary Hypnosis and Integrative Therapy, 30(2), 93-101.

Simpkins, C. A., \& Simpkins, A. M. (2012). Mindfulness and Hypnosis: The Power of Suggestion to Transform Experience by M. Yapko. 
American Journal of Clinical Hypnosis, 55(2), 199-200. https:/ / doi.or $\mathrm{g} / 10.1080 / 00029157.2013 .686417$

Stanojević, N., Nenadović, V., Fatić, S., \& Stokić, M. (2017). Exploring Factors of Stress Level in Parents of Children with Autistic Spectrum Disorder. Specijalna Edukacija I Rehabilitacija (Beograd), 16(4), 445-463. https://doi.org/10.5937/specedreh16-13861

Subandi, A., \& Rusana. (2014). Pengalaman Orang Tua Dalam Mengasuh Anak Dengan Attention Deficit Hyperactive Disorders (ADHD)/ Hiperaktif. Jurnal Kesehatan Al-Irsyad (JKA), V(1), 50-60.

Syamsuddin, \& Jafar, F. S. (2015). Pengharapan Orangtua Terhadap Anak Prasekolah Ditinjau Dari Psikologi Perkembangan Anak. Edusentris, Jurnal Ilmu Pendidikan Dan Pengajaran, 2(1), 88-97. https://doi. org/10.17509/edusentris.v2i1.163

Trimulyaningsih, N., Wulandari, E., \& Sofia, N. (2017). Qualitative Research on Islamic Psychotherapy: A Meta-synthesis Study in Indonesia. COUNS-EDU: The International Journal of Counseling and Education, 2(3), 119-130. https://doi.org/10.23916/002017025630

Valentine, K. E., Milling, L. S., Clark, L. J., \& Moriarty, C. L. (2019). The Efficacy of Hypnosis As a Treatment for Anxiety: a Meta-Analysis. International Journal of Clinical and Experimental Hypnosis, 67(3), 336363. https://doi.org/10.1080/00207144.2019.1613863

Vasel, M. Y., Farhadi, M., Paidar, M. R. Z., \& Chegini, A. A. (2016). The Efficacy of Hypnotherapy for Ego Strengthening and Negative Self-Talk in Female Heads of Households. Sleep and Hypnosis, 18(4), 74-81. https://doi.org/10.5350/Sleep.Hypn.2016.18.0111

Vickers, A., \& Zollman, C. (1999). Hypnosis and Relaxation Therapies. BMJ, 319, 1346-1349.

Wang, Y., \& Jiang, Z.-P. (2016). Effect of Parenting Styles and SelfEsteem on Subject Well-being among Chinese Medical Students. International Forum of Teaching and Studies, 12(2), 26-31. 